\title{
Peranan Audit Internal dalam Menunjang Efektivitas dan Efisiensi Biaya Operasional pada PT. Bank Negara Indonesia (Persero), TBK Cabang Medan
}

\author{
Novri Rurysun \\ Universitas Sumatera Utara \\ novryrurysun@icloud.com
}

\begin{abstract}
Abstrak
Penelitian ini dilakukan bertujuan mengetahui bagaimana pengaruh peranan audit internal dalam menunjang efektivitas dan efisiensi biaya operasional pada PT. Bank Negara Indonesia (Persero), Tbk Cabang Medan. Penelitian ini termasuk penelitian kuantitatif. Sampel diambil sebanyak 32 auditor internal PT Bank Negara Indonesia (Persero), Tbk Cabang Medan dan karyawan keseluruhan divisi operasional. Pengumpulan data menggunakan metode kuisioner dan wawancara. Kuisioner diuji validitas dan reliabilitasnya sebelum dilakukan pengumpulan data penelitian. Alat uji yang digunakan dalam penelitian ini adalah dengan menggunakan uji prasyarat analisis yang meliputi uji normalitas dan uji heteroskedastisitas. Metode analisis data yang digunakan adalah analisis regresi linier sederhana. Hasil penelitian menunjukkan bahwa peranan audit internal berpengaruh positif dan signifikan dalam menunjang efektivitas dan efisiensi biaya operasional pada PT. Bank Negara Indonesia (Persero), Tbk Cabang Medan.
\end{abstract}

Kata Kunci: Audit Internal, Efektivitas dan Efisiensi Biaya Operasional

\section{PENDAHULUAN}

Semakin luas lingkup daerah perusahaan mengakibatkan di dalam hal manajemen tidak dapat melakukan pengawasan secara langsung atau cara pribadi terhadap berjalannya operasi perusahaan. Tanggungjawab yang utama untuk menjaga keamanan harta milik perusahaan dan untuk mencegah kesalahankesalahan dan kecurangan- kecurangan terletak di tangan manajemen. Oleh karena itu, bagi manajemen mempertahankan terus adanya sistem pengawasan dan pengendalian intern termasuk sistem pelaporan yang baik adalah sangat diperlukan agar dapat melepaskan dan menyerahkan tanggungjawabnya dengan tepat. Penggunaan biaya operasi yang efesien tidak dapat terjadi dengan sendirinya namun diperlukan suatu perencanaan dan pengendalian yang memadai 
di dalam penggunaannya. Dan disinilah peran dari bagian audit internal, dari pengendalian yang memadai akan sangat membantu manajemen dalam melakukan pengendalian seluruh aktivitas yang ada di dalam perusahaan, termasuk untuk menilai tingkat efektivitas dan efisiensi biaya operasi perusahaan.

Perusahaan harus memiliki suatu bagian khusus dalam perusahaan yang dapat memeriksa dan mengindentifikasi secara cepat jika terjadi keliruan ataupun kecurangan dan melaporkannya kepada manajemen yaitu auditor internal. Selain memeriksa laporan keuangan yang dihasilkan dari sistem akuntansi, mereka juga mengkaji kebijakan-kebijakan operasional perusahaan dan memberi rekomendasi untuk meningkatkan efisiensi dan efektifitas operasi perusahaan. Dalam pelaksanaan kegiatan operasi, audit internal dapat memberikan kontribusinya dalam membantu manajemen melakukan pengawasan dan pengendalian dalam perusahaaan, sehingga kebijakan dan strategi yang ditempuh perusahaan dapat bertahan dan bahkan berkembang, terutama pengawasan pelaksanaan yang berhubungan dengan efisiensi dan efektivitas biaya operasi perusahaan.

Dalam perusahaan pelaksanaan pengawasan dapat dilakukan secara langsung oleh anggota perusahaan (Audit Internal) dan dapat dilakukan melalui suatu sistem yang disebut dengan sistem pengawasan intern. Struktur pengawasan intern perusahaan bertujuan untuk mengamankan harta benda perusahaan dengan cara meniadakan pemborosan, penyelewengan, menjamin ketelitian maupun kebenaran data akuntansi untuk meningkatkan efektivitas dan efisiensi serta mendorong kepatuhan terhadap pelaksanaan kebijakan pimpian perusahaan dengan melalui rencana organisasi dan metode maupun teknik yang serasi. Tujuan ini hanya dapat dicapai apabila unsur- unsur yang terdapat dalam struktur pengawasan intern yaitu organisasi, sistem pemberian wewenang dan prosedur pencatatan, praktek yang dan personalia dapat dipenuhi.

Audit internal dapat melaksanakan fungsinya dengan baik dan dapat memberikan hasil kerja yang optimal maka bagian audit internal ini harus memiliki kebebasan atau independensi yang memadai terhadap bagian yang di auditnya. Sikap ini mutlak yang harus dipertahankan dalam melaksanakan fungsinya sehingga manajemen melalui informasi yang diberikan kepadanya dapat mengikuti setiap perkembangan yang terjadi dalam perusahaan, dan juga manajemen dapat mempergunakan informasi tersebut sebagai bahan pertimbangan dalam pengambilan keputusan. Perbankan di Indonesia dalam melaksanakan usahanya berlandaskan pada asas demokrasi ekonomi dengan menggunakan prinsip kehati-hatian. Bank sendiri mempunyai fungsi yaitu sebagai penghimpun dan mengatur dana masyarakat dan bertujuan untuk menunjang pelaksanaan pembangunan nasional dalam rangka meningkatkan pemerataan pertumbuhan ekonomi dan stabilitas nasional kearah peningkatan kesejahteraan rakyat banyak. (Pasal 2,3,4 UU perbankan tahun 1998).

Dalam hal kredit macet pihak bank perlu melakukan penyelamatan, sehingga tidak akan menimbulkan kerugian. Penyelamatan yang dilakukan apakah dengan memberikan keringanan berupa jangka waktu atau angsuran terutama bagi kredit terkena musibah atau melakukan penyitaan bagi kredit yang sengaja lalai untuk membayar. Terhadap kredit yang mengalami kemacetan sebaiknya dilakukan penyelamatan sehingga bank tidak mengalami kerugian (Kasmir, 2008). Risiko yang diuraikan dalam peraturan Bank Indonesia No.11/25/PBI/2009 sebagian bersumber dari kegiatan operasional yang dilaksanakan. Dalam pelaksanaan kegiatan yang dilakukan oleh perbankan perlu pengawasan yang 
cukup untuk meminimalisir risiko sehingga perusahaan sebaiknya melakukan audit operasional, yaitu alat bantu bagi manajemen khususnya dalam fungsi pengendalian demi tercapainya tujuan perusahaan yang telah ditetapkan.

PT. Bank Negara Indonesia (Persero), Tbk adalah suatu badan usaha milik pemerintah Indonesia yang menghimpun dana dari masyarakat dalam bentuk tabungan dan menyalurkan kembali kepada masyarakat dalam bentuk kredit untuk menunjang peningkatan ekonomi masyarakat.Memberikan pelayanan prima kepada nasabah melalui jaringan kerja yang tersebar luas dan didukung oleh sumber daya manusia yang profesional dengan melaksanakan praktek Good Corporate Governance.Memberikan keuntungan dan manfaat yang optimal kepada pihak-pihak yang berkepentingan. PT. Bank Negara Indonesia (Persero), Tbk cabang Medan dalam melakukan oleh bagian Internal Control Staff yang bertanggungjawab atas seluruh kegiatan operasi perusahaan. Permasalahan yang dihadapi oleh perusahaan adalah laporan mingguan operasional kantor Cabang Pembantu yang akan diaudit oleh Internal Control terkadang mengalami keterlambatan sehingga hal- hal penting perlu segera dilaporkan kepada kepala cabang tidak segera dapat diketahui untuk melakukan tindakan lebih lanjut.

\section{Audit Internal}

\section{LANDASAN TEORI}

Audit internal merupakan audit yang ditujukan untuk perbaikan kinerja dengan kegiatan meliputi pengujian, penilaian, efektivitas dan kecukupan dalam efektivitas penerapan pengendalian intern yang ada dalam organisasi.

\section{Efektivitas dan efisiensi biaya operasional}

Menurut Handayaningrat dalam Rizal (2009), efektivitas adalah pengukuran dalam arti tercapainya sasaran atau tujuan yang telah ditentukan sebelumnya. Menurut Randal J.Elder, Mark S Beasley, dan Alvin A. Arens (2010 : 824) menyatakan bahwa "In general, effectiviness refers to meeting objectives". Sedangkan menurut Bhayangkara, IBK (2008:14), efektivitas didefenisikan: "Efektifitas dapat dipahami sebagai tingkat keberhasilan suatu perusahaan untuk mencapai tujuannya." Sawyer, B Lawrence (2005:211) mendefenisikan efektivitas sebagai berikut: "Efektifitas menekankan hasil aktual dari dampak atau kekuatan untuk menghasilkan dampak tertentu. Sesuatu bisa jadi efektif tetapi tidak efisien dan ekonomis".

\section{METODE PENELITIAN}

Penelitian dilakukan berupa studi kuantitatif. Penelitian kuantitatif merupakan penelitian yang bertujuan untuk mengetahui derajat hubungan dan pola/bentuk pengaruh antar dua variabel atau lebih. Adapun populasi dan sampel dalam penelitian ini sebanyak 32 orang yang terdiri atas 20 responden yang merupakan auditor internal PT Bank Negara Indonesia (Persero), Tbk Cabang Medan dan 12 responden yang merupakan karyawan keseluruhan divisi operasional PT. Bank Negara Indonesia (Persero), Tbk Cabang Medan. Sedangkan teknik pengumpulan data pada penelitian ini diperoleh dengan teknik observasi, wawancara dan kepustakaan. Pengolahan data menggunakan perangkat lunak SPSS 16.0For Windows. Analisis statisitk inferensial dalam penelitian ini meliputi: uji asumsi klasik, regresi analisis jalur, uji hipotesis. 


\section{HASIL DAN PEMBAHASAN}

Penelitian ini menunjukkan bahwa peranan audit internal berpengaruh positif dan signifikan dalam menunjang efektivitas dan efisiensi biaya operasional pada PT. Bank Negara Indonesia (Persero), Tbk Cabang Medan, dimana hasil menunjukkan bahwa nilai signifikan sebesar $0,000<0,05$. Hal ini dapat dinyatakan bahwa audit operasional dapat meningkatkan efektivitas dan efisiensi melalui saran dan rekomendasi yang diberikan oleh auditor dengan catatan manajemen harus melakukan tindak lanjut. Peran auditor tidak berhenti sampai disini tetapi auditor harus memonitor perkembangan pelaksanaan tindak lanjut perbaikan yang telah dilakukan. Ini membuktikan bahwa auditor tidak hanya sebatas menemukan masalah serta memberikan saran dan rekomendasi tetapi juga menekankan bagaimana pemberian kredit sesuai dengan prosedur yang ada sehingga pelaksanaan audit operasional terbukti dapat meningkatkan efektivitas dan efisiensi biaya operasional.

\section{KESIMPULAN}

Berdasarkan hasil analisis yang telah dilakukan dapat ditarik kesimpulan yaitu peranan audit internal berpengaruh positif dan signifikan dalam menunjang efektivitas dan efisiensi biaya operasional pada PT. Bank Negara Indonesia (Persero), Tbk Cabang Medan.

\section{REFERENSI}

Afrianiswara, E.I. 2010.Peranan Audit Internal dalam Menunjang EfektivitasPengendalian Internal Kredit Investasi Pada PT Bank X. Surabaya:Sekolah Tinggi Ilmu Ekonomi Perbanas Surabaya.

Alvin A. Arens, Randel J. Elder dan Mac S.Beasley. 2010. Auditing andAssurance Services An Integrated Approach 13, , edition. New jersey:Pearson.

Astasari, V. 2011.Peran Audit Operasional Dalam Meningkatkan EfektivitasKegiatan Perkreditan (Studi Kasus Pada Bank Nagari Cabang Utama Padang).Padang: fakultas Ekonomi Univrsitas Andalas.

Bayangkara, IBK. 2008. Audit Manajemen (Prosedur Dan Implementasi). Jakarta:Salemba Empat.

Boynton, C.W, Johnson, N.R. 2006.Modern Auditing Assurance Services andThe Integrity Of Financial Reporting, $8^{\text {th }}$ edition. New York: John Wileyand Sons.Inc.

Dan M. Guy, C. Wayne Alderman, Alan J. Winter.2003. Auditing, $5^{\text {th }}$ edition. Jakarta: Erlangga.

Dean, J, Champion. 1990. Basic Statistics For Social Research, $2^{\text {nd }}$ edition. NewYork: Mac Milan Publishing Co.

Hidzriadi, S. 2008. Manfaat Audit Operasional Dalam Efektivitas PemberianKredit (Studi Kasus pada PT Bank Jabar Cabang Utama Bandung). Bandung: Fakultas Ekonomi Universitas Widyatama.

Ismail. 2010. Akuntansi Bank: Teori dan Aplikasi Dalam Rupiah. Edisi ke-1. Jakarta: Kencana.

Kasmir. 2003. Manajemen Perbankan. Edisi Ke 4. Jakarta: Raja Grafindo Persada. 
Peraturan Bank Indonesia Nomor: 5/8/PBI/2003 Tentang Penerapan Manajemen Risiko Bagi Bank Umum.

Peraturan Bank Indonesia Nomor: 9/6/PBI/2007 Tentang Penilaian Kualitas Aktiva Bank Umum.

Peraturan Bank Indonesia No.11/25/PBI/2009-Perubahan Atas PBI No.5/8/PBI/2003 Tentang Penerapan Manajemen Risiko Bagi Bank Umum.

Prameswari, M. 2008. Audit Operasional Atas Prosedur Pemberian Kredit UntukMeningkatkan Efektivitas Dan Efisiensi Pada PT BNI (persero) Tbk, Wilayah 02 Padang. Padang: Fakultas Ekonomi Universitas Andalas.

Sawyer, B. Lawrence, Dittenhofer, A, Motimer, and Scheiner, H.James. 2005.Internal Auditing. The Institue of Internal Auditor, Diterjemahkan oleh : Desi Adhariani, Buku 1 Edisi 5. Jakarta: Salemba Empat.

Sekaran, Uma, Bougie, Roger. 2009. "Research Methods For Business : A Skill Building Approach, $5^{\text {th }}$ ed ". United Kingdom : John Wiley And Sons Ltd.

Sugiyono. 2008. Metode Penelitian Kuantitatif Kualitatif dan R\&D. Bandung: Alfabeta.

Suyatno, Thomas. 2001. Dasar-Dasar Perkreditan. Edisi Ke 4, Jakarta: Gramedia Pustaka Utama

Tunggal, Amin Widjaya. 2001. Audit Operasional (Suatu Pengantar). Jakarta: Harvindo.

Undan-Undang Perbankan Negara Republik Indonesia Nomor 10 Tahun 1998.

Widjayanto Nugroho. 2001. Pemeriksaan Operasional Perusahaan. Jakarta: Lembaga Penerbitan Fakultas Ekonomi Indonesia. 